\title{
A Study on Students' Autonomous Learning Ability, Teacher- student Interaction and Its Influence on Academic Development during the COVID-19 Epidemic
}

\author{
Xiaotian $\operatorname{Sun}^{1}$ \\ ${ }^{1}$ School of Education, Hebei Normal University, Shi Jiazhuang, He Bei 05000, China
}

\begin{abstract}
During the COVID-19 epidemic in 2020, online teaching was in full swing. However, due to a variety of factors, there are significant differences in students' academic development at this stage. This paper collects the experience and evaluation of undergraduate students' learning ability, teacher-student interaction and academic development in this context. It is found that students' autonomous learning ability has a significant effect on their academic development, compared with little effect on teacher-student interaction. Based on these results, this paper puts forward some suggestions on the evaluation system of teachers and the guidance of students' autonomous learning.
\end{abstract}

\section{INTRODUCTION}

In order to carry out the important instruction of General Secretary XI Jinping on determined to fight and win the battle against the epidemic and the decision and deployment issued the CPC Central Committee and the State Council, as well to prevent and control the epidemic and ensure the health of teachers and students, the Ministry of Education initiated the policy of "stop classes, continue learning" [1][2].required colleges and universities to actively carry out online teaching. Online teaching brings both convenience and disadvantages to teachers and students, some studies[3].indicate that the hardware facilities, network environment and colleges support are inadequate; the inconsistency of teaching platform, lack of class organization and timely teacherstudent interaction, the students are difficult to concentrate on learning; heavy homework burden, difficult to solve questions timely etc. This paper chooses to study the influence of students' autonomous learning ability and teacher-student interaction on academic development, and puts forward some suggestions for education and teaching.

\section{LITERATURE REVIEW}

\subsection{Autonomous Learning Ability}

Since its inception, the term of autonomous learning has been widely concerned by psychology schools. Humanistic psychology puts forward to integrate emotional and intellectual education into the inner learning of optimal growth, and advocates that students should be regarded as the subject of learning, and studentscentered learning should be carried out to promote the freedom of learning and the initiative of creativity[4].Constructivism emphasizes the process of students' active construction, and believes that the construction of students' autonomous learning ability not only depends on the students themselves, teachers also play an important role in promoting students' autonomous learning[5].The idea of lifelong learning education suggests that all members should adhere to the selfeducation beyond the school and give full play to their own initiative, and the school should also provide the environment for lifelong learning[6].Social cognitive theory suggests that when students are active participants in metacognition, motivation and behavior, their learning is autonomous[5].In this paper, the author thinks that students with strong autonomous learning ability should have positive learning attitude and learning behavior.

In recent years, some scholars at home and abroad have conducted empirical research on college students' autonomous learning ability and academic achievement. ZHOU Yangen, SANG Qingsong and GE Minggui argue that college students' autonomous learning plays a predictive role in academic achievement in the study of the relationship between autonomous learning, achievement goal orientation and academic achievement[7].In the study of the relationship between learning motivation, attribution, self-efficacy and students' self-control learning behavior, ZHOU Yong and DONG Qi put forward that the self-control learning behavior is proportional to the internal control score of success attribution, but has little relationship with failure attribution, and the self-control learning behavior is positively correlated with the self-efficacy. In their paper, learning motivation, attribution and self-efficacy are several important internal factors that influence selfcontrol learning behaviour[8]. 


\subsection{Interaction between Teachers and Students}

As for teacher-student interaction, different scholars have proposed different definitions of this concept. Some scholars define it as the condition for effective teaching in the classroom, teachers and students, based on equal relationship, in order to achieve the expected teaching tasks and goals, using teaching tools, in reasonably designed problem-solving that occur in interaction and dialogue[9].In the papers of GAN Yongtao, LOU Chengli and XU Maijin, the author also discuss the nature of teacher-student relationship, they all argue that teacherstudent relationship should not only be an interactive relationship, but also an emotional relationship. According to the existing research, most of studies focus on the classroom interaction ontology and on the classroom interaction practice. Or from the mode, type, and influencing factors to study the teacher-student interaction construction. However, there are few researches emphasize on the influence of teacher-student interaction from the results of academic research. In this paper, teacher-student interaction is interpreted as a dialogue on the basis of equality with positive long-term impact on students' academic or personality aspects.

\subsection{Academic Development}

In the present study, scholars have different definitions of academic development. DU Yuhong and LIANG Wenyan equate academic development with students' daily test scores[10].WANG Dapin believes that academic development consists of students' engagement, their academic achievement and satisfaction with the school and teacher-student interaction[11] YANG Po defines individual academic development in terms of admission opportunities, completion rates and student achievement[12]. In his research, HUANG Fan discusses the academic development of middle school students from three aspects: academic achievement and satisfaction, learning attitude and learning ability[13]. In this paper, the author will define and study academic development from four aspects: learning attitude, academic completion rate, learning efficiency and student achievement.

In terms of the influencing factors of academic development, scholars mainly attribute to parenting style, personality[14], family conditions and social assistance etc., while there are few studies on the influence of teacher-student interaction and students' autonomous learning ability on academic achievement development. In the author's opinion, first of all, it is the most important task for college students to master professional knowledge and acquire professional skills. Therefore, the first dimension of academic development is mainly measured by academic achievements, research achievements, certificates obtained, etc. Secondly, the purpose of education is to educate people, so the emotional attitude of college students is also within the scope of academic development. The academic development of this paper is measured on the basis of the above-mentioned two dimensions.

\section{RESEARCH METHOD}

Firstly, the questionnaire was designed with reference to Motivated Strategies for Learning Questionnaire (MSLQ)[15], A Study on Current Status and Countermeasures of Teacher-Student Interaction between Mentors and Graduate Students and Teachers[17] by HE Jing, Understand the Relationship between Social Support, Psychological Capital and Academic Achievement of College Students[17] by WU Shuangshaung. The questionnaire included basic demographic variables as well as the survey of the current situation of teacherstudent interaction, autonomous learning ability and academic development.

Table.1 Variables Description Statistics

\begin{tabular}{|c|c|c|c|c|c|}
\hline Variable & \multicolumn{5}{|c|}{ Sample Size Mean Value Standard Deviation Minimum Maximum } \\
\hline \multicolumn{6}{|l|}{ Explained variable } \\
\hline Academic development & 53 & 41.83 & 7.585 & 19 & 52 \\
\hline \multicolumn{6}{|l|}{ Explanatory variable } \\
\hline Interaction between teachers and students & 53 & 48.509 & 8.03 & 22 & 56 \\
\hline Autonomous learning ability & 53 & 42.358 & 6.406 & 21 & 52 \\
\hline \multicolumn{6}{|l|}{ Control variable } \\
\hline Gender & 53 & & & & \\
\hline Male $(=1) \%$ & & 20.755 & & & \\
\hline Female $(=2) \%$ & & 79.245 & & & \\
\hline Majors & 53 & & & & \\
\hline Humanities and Social Sciences $(=1) \%$ & & 73.585 & & & \\
\hline Science $(=2) \%$ & & 11.321 & & & \\
\hline Engineering $(=3) \%$ & & 9.434 & & & \\
\hline Agriculture $(=4) \%$ & & 0 & & & \\
\hline Medicine $(=5) \%$ & & 5.66 & & & \\
\hline Grade & 53 & & & & \\
\hline
\end{tabular}




$\begin{array}{lr}\text { Class of } 2019(=1) \% & 13.208 \\ \text { Class of } 2018(=2) \% & 77.358 \\ \text { Class of } 2017(=3) \% & 5.66 \\ \text { Class of } 2016(=4) \% & 3.774\end{array}$

Questionnaires were distributed to college students, as most of them rely on teachers teaching online, and the data collected were more representative and persuasive.

Questionnaire data were analyzed by multiple linear regression model in Stata. On the basis of stripping out the influence of control variables on academic achievement, this paper examines the effects of teacher-student interaction and autonomous learning ability on academic achievement.

The study takes the $\mathrm{Yi}=\beta 0+\beta 1 \mathrm{X} 1 \mathrm{i}+\beta 2 \mathrm{X} 2 \mathrm{i}+\ldots+\beta \mathrm{kXk}$ $\mathrm{i}+\mu \mathrm{i} i=1,2, \ldots, \mathrm{n}$ model to verify the influence of teacherstudent interaction and autonomous learning ability on academic achievement. In the formula, $\mathrm{k}$ represents the number of explanatory variables, $\beta \mathrm{j}(\mathrm{j}=1,2, \ldots \mathrm{k})$ represents the regression coefficient.

\section{DATA ANALYSIS}

There were 53 valid questionnaires in the study, 11 male respondents and 43 female respondents. 39 of them majored in humanities and social sciences, 6majored in science, 5 majored in engineering and 3 majored in medicine. 7 students from Class of 2019, 41 from Class of 2018, 3 from Class of 2017 and 2 from Class of 2016.

Table.2 Correlation Analysis of the Influence of Autonomous Learning Ability and Teacher-student Interaction on Academic Development

\begin{tabular}{cc}
\hline & Academic Development \\
\hline Autonomous learning ability & $0.936^{* * *}$ \\
& $(0.126)$ \\
\hline Interaction between teachers and students & 0.123 \\
& $(0.097)$ \\
\hline Gender & $1.062^{*}$ \\
& $(1.448)$ \\
\hline Grade & 1.341 \\
& $(0.749)$ \\
\hline Place of residence & -0.216 \\
& $(0.943)$ \\
\hline Intercept & -7.579 \\
& $(3.739)$ \\
\hline Sample size & 53 \\
\hline LR Chi-Square value & $34.34 * * *$ \\
\hline
\end{tabular}

Note: $(1)^{* * *} \mathrm{p}<0.001, * * \mathrm{p}<0.01,{ }^{*} \mathrm{p}<0.05 ;$ (2) Standard error in bracket

After the data processing, it was found that the effects of autonomous learning ability and teacher-student interaction on academic development were significantly correlated, while that of teacher-student interaction was not significantly related.

There are several possible reasons for this phenomenon:

1. The teacher-student relationship of teachers as the subject and students are led by teachers. For a long time, teachers are the subject of teaching and remain in an authoritative position, learning during undergraduate is the basic knowledge of a certain field. Students have their own preliminary ideas about their majors, however due to insufficient accumulation of knowledge, it is still difficult for them to express their views systematically. The viewpoint of "score only" in universities has been reduced, the students are less demanding on studies, and most students no longer seek advice from teachers for every question, so the relationship between teachers and students becoming flat, and the opportunity of autonomous learning is increasing.

2. The "valuing research at the expense of teaching" promotion mechanism[18] for college faculty. The current research-oriented and quantitative evaluation system for titles in research-oriented colleges and the problems caused by teachers' actions in teaching and research, such as "valuing quantity of papers published at the expense of quality", "valuing research at the expense of teaching" and "bird courses", all contributed to the deterioration of classroom atmosphere and teacher-student relationship. Teachers devote more time and effort to research, resulting in the desalination of the teacher-student relationship and interaction. Therefore, online teaching during the epidemic has little impact on the interaction between teachers and students.

3. Unbalanced proportion of teachers and students due to colleges enrollment expansion. Research shows[19]that the enrollment expansion causes a decrease in the teacher- 
student ratio in colleges, where teachers are responsible for too many students, to care about the academic development of everyone. At the same time, with the increasing number of students, the gap of teachers are increasing as well, that means teachers have to take on more courses. As a result, the interaction between students and teachers is in a low-frequency.

4. Independent and autonomous learning style of college students. College students' learning style is the key factor in their learning process. The classroom experience of college students in our country is better and the learning style is more scientific, but there is room for further improvement. As the classroom teaching can't fully meet the students' demands for knowledge and achievement, there are more opportunities for them to study independently. Online learning reduces the effective communication between students and others, therefore, students' autonomous learning ability is particularly important.

\section{SUGGESTION}

1. Teacher evaluation. First of all, in the evaluation system for teachers, teaching quality and students' evaluation should be improved. In this questionnaire, the majority of the respondents were from a non-key college. The main reason for the low influence of teacher-student interaction is that there is little relationship between teacher's classroom teaching content and examination content, so students don't discuss what they have learned in class with teachers. Therefore, it is necessary to collect various standards for teaching quality, including the work completion, the contribution to the improvement of students' academic development, as well as reports from other teachers, students' rating on teachers, and the improvement of students' innovation ability under the training of teachers. At the same time, pay attention to the teachers' opinions and suggestions on the evaluation mechanism, colleges should work together with teachers to formulate the sound promotion mechanism. In a word, it is necessary to make teachers still regard teaching and education as their first priority and pay close attention to the students' demands, so as to further improve students' academic development.

2. Students' autonomous learning. College students' autonomous learning ability has a significant impact on their self-development, thus the colleges should take active measures to promote the students' autonomous learning ability. The main problem of college students' online learning is lack of good study habits and weak selfcontrol ability, and when facing a wide range of learning resources, they will be "lost in the information", do not know how to take advantage their own learning resources. Therefore, in the process of college students learning, colleges and teachers should play the role of "instructors" for students, plan the general direction of course learning and put forward curriculum requirements. In terms of student psychology, they should also guide the student to clarify own life goal and be the life planner of their own life. In the meanwhile, teachers should optimize students' learning environment, provide students with high-quality learning materials, and update the required materials promptly so as to make it more convenient for autonomous learning.

\section{REFERENCES}

1. The Ministry of Education of the People's Republic of China. Notice on Supporting Education and Teaching with Information Technology during Epidemic Prevention and Control issued by Office of the Leading Group of the Ministry of Education of the People's Republic of China for Novel Coronavirus Prevention and Control (JJT H [2020]No.7) [Z].202002-06.

2. Ministry of Education of People's Republic of China. Guidance on Organization and Management of Online Teaching in Higher Education Institutions during Epidemic Prevention and Control issued by Office of the Leading Group of the Ministry of Education of the People's Republic of China for Novel Coronavirus Prevention and Control (JGT [2020] No.2)[Z].2020-02-04.

3. JIA Wenjun, GUO Yuting, et al. Cluster Analysis of College Students' Online Learning Experience[J]. China Higher Education Research, 2020, (04), 23-27.

4. Zimmerman, BJ. A social cognitive view of self--regulated academic learning. Journal of Educational psychology, 1989, 81

5. Zimmerman, BJ. Becoming a self-regulated learner[J], Theory in practice, 2002.41:64-67

6. McCombs BL. Self-regulated learning and academic Comphenomena achievement logical view[M]. 2003

7. ZHOU Yangen, SANG Qingsong, GE Minggui. A Study on the Relationship between Self-Directed Learning, Achievement Goal Orientation and Academic Achievement of College Students[J]. Journal of Psychological Science, 2010 (01):79-81.

8. ZHOU Yong, DONG Qi. A Study on the Relationship between Learning Motivation, Attribution, Selfefficacy and Students' Self-monitoring of Learning Behavior[J]. Psychological Development and Education, 1994 (3):30-32

9. ZHANG Ziping. Study on Teacher-Student Interaction Behavior in Effective Teaching in Classroom[D]. Shanghai Normal University, 2015

10. DU Yuhong, LIANG Wenyan. The Influence of Educational Engagement on the Development of Students-Reflection on the Research and Design of the Impact Assessment of the Xifa Project[J]. Journal of Educational Studies, 2010, 6 (06):61-66.

11. WANG Dapin. Analysis of College Students' Academic Development and Countermeasures--On the Construction of Academic Counseling System in Colleges and Universities[J]. Education Research, 2014, 35 (05):43-49.

12. YANG Po. The Influence of College Students 
Funding on Academic Development[J]. Tsinghua Journal of Education, 2009, 30 (05):101-108.

13. HUANG Fan. A Survey of the Status Quo and Influencing Factors of Family Cultural Capital on the Academic Development of Secondary School Students[J]. Theory and Practice of Contemporary, 2013, 5 (11):10-13.

14. YUAN Qing. Study on the Relationship between Parenting Style, Resilient Personality and Academic Development among Senior High School Students[D]. Jiangnan University, 2019.

15. Pintrich, Paul R.A Manual for the Use of the Motivated Strategies for Learning Questionnaire. $<$ unk $>$ https://eric.ed.gov/?id=ED338122</unk

16. HE Jing. A Study on Current Status and Countermeasures of Teacher-Student Interaction between Mentors and Graduate Students and Teachers[D].Shihezi University, 2020

17. WU Shuangshaung. Understand the Relationship between Social Support, Psychological Capital and Academic Achievement of College Students[D]. Shandong Normal University, 2013.

18. ZHOU Yurong, SHEN Hong. An Analysis of the Effect of Current Teacher Evaluation on University Faculty Development[J].Tsinghua Journal of Education, 2016 (9).

19. WANG Hongcai. Investigation on the Influence of College Enrollment Expansion on Teaching Quality[J]. Tsinghua Journal of Education, 2001 (04):145-153. 